\title{
Investigation on the Storage Stability of Packaged Water Commonly Produced in Ilorin Metropolis, Kwara State, Nigeria
}

\section{Fatai Okeola}

University of llorin

\section{Taofiqat Abu}

University of llorin

AMINAT ADERONKE MOHAMMED ( $\nabla$ mohammed.aa@unilorin.edu.ng )

University of llorin https://orcid.org/0000-0002-5367-7600

\section{Michael Orosun}

University of Ilorin

Modupe Obinaike

University of Ilorin

Adeboje Mariam

University of llorin

\section{Research Article}

Keywords: Sunlight, llorin, Health Risk, storage condition, Microbial Analysis

Posted Date: August 30th, 2021

DOl: https://doi.org/10.21203/rs.3.rs-848220/v1

License: (9) (i) This work is licensed under a Creative Commons Attribution 4.0 International License.

Read Full License 
Investigation on the Storage Stability of Packaged Water Commonly Produced in Ilorin

\section{Metropolis, Kwara State, Nigeria}

\section{Okeola F.O', Abu T.O., Mohammed A. A ${ }^{1 *}$, Orosun, M.M²., Obinaike M.T ${ }^{1}$, Adeboje B.M ${ }^{1}$ \\ ${ }^{1}$ Department of Industrial Chemistry, Faculty of Physical Sciences, University of Ilorin, Kwara State, Nigeria. \\ ${ }^{2}$ Department of Physics, Faculty of Physical Sciences, University of Ilorin, Kwara State, Nigeria. *Corresponding author email: mohammed.aa@unilorin.edu.ng; tiwatope1302@gmail.com Phone Number: +2348068302379}

\section{ABSTRACT}

This study investigated the effects of storage conditions on the physicochemical parameter, microbial loads and health risks assessment of randomly 30 selected sachet and bottle water brands (A, B and C) in Ilorin Metropolis. Random sampling procedures were used to collect samples from three different brands and subjected to three different storage conditions; immediately (initial), mild sunlight and intense sunlight condition. The heavy metals $(\mathrm{Cr}, \mathrm{Pb}$ and $\mathrm{Fe})$ investigated in this study were above the permissible limits (WHO, SON). The presence of TBC, TCC, FCC and TFC in all the water samples analyzed showed no effective quality control system. Incremental lifetime cancer risk (ILCR) assessment revealed a carcinogenic health risk to the populace drinking this water. It can be deduced from this study that water stored under sunlight for a long period of time is not good for human consumption and therefore adequate monitoring by the appropriate agencies are emphasized.

Key Words: Sunlight, Ilorin, Health Risk, storage condition, Microbial Analysis.

\section{INTRODUCTION}

Water is an essential liquid for human day to day activities which contain two atoms of hydrogen and one atom of oxygen. It is a basic need for human existence that is require to maintain personal hygiene, prevention of diseases and food production (Oparaocha et al. 2010; Edema et al. 2011; Adegoke et al. 2012). Water fall as rain and can be found in lakes and rivers which are the primary sources of fresh water for agriculture, human consumption, and industrial uses (Chapagain and Hoekstra 2007) Portable water is a source of water that is properly treated and free of contaminants such as heavy metals, microorganisms, nitrates, sulphates among others (Singh and Mosley 2003).

Previous researchers have estimated that over 1.8 million people in most of the developing countries lack adequate good water supply as a result of increase in population (Oyelude and 
Ahenkorah 2012; Akinde et al. 2011) and this pave way for packaged water as a fast-growing business in most developing countries which is very lucrative due to the rate at which consumers buy this packaged water (sachet and bottle). Sachet and bottle water can come from a variety of sources, including groundwater from a well, water from a protected spring, or water from a public water supply. However, there is a great risk associated with water produced in an unsafe and unhygienic environment (Tortora et al. 2002) and this often resulted into several health challenge s among children and infants especially water borne diseases like diarrhea, typhoid, cholera, hepa

titis and dysentery among others (WHO 2011)

Similarly, several researchers reported that the main source of problem associated with production of sachet and bottle water is the way of handling during the production process, storage for several weeks and contamination which can also be attributed to the use of pipe for a longer period (Tambeka et al. 2006; Kendall 2007). In most of the cities and towns in Nigeria, sachet and bottle water is often stored and exposed to direct sunlight without any knowledge on the effect of the quality of this packaged water on the populace buying it. However, there is need to investigate the effect of exposing both sachet and bottle water to sunlight under different conditions.

The aim of this research is to determine the physicochemical, heavy metal concentrations and microbial quality and human health risk assessment of some sachet and bottle water sold within Ilorin city, Kwara state, Nigeria, and compared the results obtained from the analysis with Standard Organization of Nigeria (SON) and World Health Organization (WHO) permissible limits

\section{EXPERIMENTAL}

\section{Sample Collection and Preparation}

A 30 randomly selected sachet and bottle water of three different brands (A, B and C) were obtained from three factories in Ilorin, Kwara state. The samples from each brand were divided into three (3) groups which includes 1,2 and 3. Group 1 samples were analyzed immediately (initial) after purchased from the factories. Group 2 samples were stored in a container and exposed to sunlight for six weeks (mild condition). While Group 3 were stored and exposed directly (intense condition) to the sunlight without a container for six weeks.

\section{Physicochemical Parameters}

The $\mathrm{pH}$ was measured using a $\mathrm{pH}$ meter Ino Lab Tech 7310 digital multimeter which give direct value of $\mathrm{pH}$ and it was calibrated with buffer solutions ( $\mathrm{pH} 4$ and 7). Thermometer was used to 
measure the temperature of the water samples in-situ. Electrical conductivity (EC) and total dissolved solid (TDS) were determined by HANNA Digital multimeter and it was calibrated with potassium chloride solution. Alkalinity, hardness, chloride and calcium contents were determined titrimetrically. The concentration of magnesium contents was determined by subtracting the concentrations of calcium from total hardness. Sulphate contents were determined turbidimetrically and Nitrate contents were determined by Brucine method (APHA 2017).

\section{Heavy Metals Determination}

$50 \mathrm{~mL}$ of each water samples (sachet and bottle) were digested by aqua regia method of digestion using $\mathrm{HNO}_{3} / \mathrm{HCl}$ in 1:3 ratio and was later analyzed for presence of heavy metals (Chromium $\mathrm{Cr}$, lead $\mathrm{Pb}$ and Iron Fe) in triplicates using Atomic Absorption Spectrophotometer ((Buck Scientific Model 210 VGP, USA).

\section{Microbiological Parameters}

Total bacteria count (TBC), Total coliform count (TCC), Faecal coliform count (FCC), and Total fungal count were also determined in each of the water samples using multiple tube fermentation and membrane filtration methods (APHA 1998).

\section{Human health risk assessment}

90

The association between the concentration of the toxic metals ( $\mathrm{Fe}, \mathrm{Pb}$, and $\mathrm{Cr}$ ) and their apparent risk to human health is generally appraised by the human health risk assessment models established by the USEPA (2004) (2009) (2011) and UNC (2011). This technique is accessible by means of the risk assessment information system (RAIS) (USEPA 2004) and the toxicological profiles presented by the United State Environmental Protection Agency's Integrated Risk Information System (IRIS) (Orosun et al. 2020; Orosun 2021; USEPA 2007), in collaboration with the United State Agency for Toxic Substances and Disease Registry - Toxicological profiles (ATSDR 2007). In this current research, the risk evaluation of the toxic elements $(\mathrm{Cr}, \mathrm{Pb}$ and $\mathrm{Fe})$ was initiated by primarily evaluating the chronic daily intake (CDI) of each of the metals through the possible exposure pathways (in this case, ingestion pathway).

For the ingestion pathway of exposure, the chronic daily intake (CDI) (mg/L/day) was evaluated by the following equations set by USEPA (2001).

$$
\mathrm{ADI}_{\text {ing-water }}=\frac{C w \times I n g R w \times E F \times \mathrm{ED}}{B W \times A T} .
$$


Where $\mathrm{C}_{\mathrm{w}}$ is the concentration of the given heavy metal in the sampled drinking waters. $\mathrm{BW}$ is bodyweight of the exposed person ( $70 \mathrm{~kg}$ ), ED is the lifetime exposure period (average life expectancy of Nigerians is 55 year), EF is the exposure frequency ( 365 day/year), AT is the time period through which the dose is averaged (ED x 365 days) and $\operatorname{IngR}_{\mathrm{w}}$ is the ingestion rate of the drinking waters (2 L/day).

\section{The Carcinogenic and Non-Carcinogenic Risk Assessment}

The calculated Chronic daily intake (CDI) in proportion to oral reference dose $\left(\mathrm{RfD}_{\text {oral }}\right)$ of the selected heavy metals branded as target Hazard Quotient (HQ) (Orosun et al. 2020; USEPA 2001), is generally utilized to highlight the severity of the non-carcinogenic risks. The formula is given by USEPA as;

$$
\mathrm{HQ}=\frac{A D I}{R f D}
$$

where CDI is the chronic daily intake of a given toxic constituent and RfD is the persistent reference dose for the element i.e. for the $\mathrm{Cr}$, $\mathrm{Fe}$ and $\mathrm{Pb}$, we have 3.0E-03, 9.0E-02, 3.5E-03 mg/Lday (USEPA 2001). If the HQ $>1$, however, there is an increased probability of unfavorable health effects to the exposed populace. Conversely, if $\mathrm{HQ}<1$ subsequently there is no possibility of negative health effects (Rinklebe et al. 2019).

The hazard index (HI) is the sum of the HQ calculated using equation (11) (Rinklebe et al. 2019; USEPA 2001; Orosun 2021).

$$
\mathrm{HI}=\sum H Q
$$

According to the risk classification system assembled by International Agency for Research on Cancer (IARC) and WHO, among the heavy metals analyzed in this study, $\mathrm{Pb}$ and $\mathrm{Cr}$ were human carcinogens, and their carcinogenic slope factors are $8.5 \times 10^{-3}$ and $0.5(\mathrm{mg} / \mathrm{L} / \text { day })^{-1}$ respectively (Orosun et al. 2020). The carcinogenic risk estimation gives an index of risk or possibility of an aimed people to develop cancer of several types as a result of the ingestion of the carcinogens in the drinking waters over a projected lifetime (Orosun et al. 2020; Isinkaye2018). Incremental Lifetime Cancer Risk (ILCR) that presents the carcinogenic risk was calculated using equation (13) (Orosun et al. 2020; Isinkaye2018).

$$
\mathrm{ILCR}=\mathrm{ADI} \times \mathrm{SF}
$$


Where CDI (mg/L/day) and SF (mg/L/day) $)^{-1}$ are the mean daily consumption of the heavy metals and the carcinogenic gradient factor. Cancer risk higher than $1 \times 10^{-4}$ are considered high as they pose higher cancer threat while values below $1 \times 10^{-6}$ are assumed not to cause any cancer risk to the populace; the suitable range is flanked by $1 \times 10^{-4}$ and $1 \times 10^{-6}$.

\section{RESULTS AND DISCUSSION}

The physicochemical parameters, heavy metals and microbiological analysis examined showed considerable variations in the sachet and bottle water samples analyzed as shown in the figs. (1 5) below. The $\mathrm{pH}$ value of all the water brands analyzed ranged from $6.56-8.22$. Bottle water $\mathrm{pH}$ recorded 6.65- 7.28 while sachet water recorded 7.78 - 8.22 as shown in fig. 1 and 2 below. This is similar to the previous report by some researchers (Sulaiman et al. 2011; Uwah et al. 2014; Duru et al. 2017). Water samples stored at mild sunlight exposure (Group 2) ranged from 6.79 - 8.01. While those stored at intense sunlight exposure ranged 6.62 - 8.00 (Group 3). Brand C water samples in both sachet and bottle water recorded the highest $\mathrm{pH}$ value of 8.22 and 7.28 (Group 1) respectively. Increase in $\mathrm{pH}$ of water can lead to an increase in bacteria population (Sunday et al. 2011). Brand A recorded the lowest $\mathrm{pH}$ in both sachet (7.78) and bottle water (6.56). There was an increase in the $\mathrm{pH}$ values which could be due to the different mode of storage as shown in table 5 below. The $\mathrm{pH}$ values of all the water brands were within the recommended $\mathrm{pH}$ range (WHO 2006; SON 2007; WHO 2011) as shown in table 1 below.

The mean temperature value ranged from $28.6{ }^{\circ} \mathrm{C}-30.6{ }^{\circ} \mathrm{C}$ for all brands water samples analyzed in both bottle (fig. 1a) and sachet water (fig. 1b) in initial, mild and intense group of storage conditions. Samples of water analyzed immediately (initial) after purchased from the factories ranged between $28.7^{0} \mathrm{C}-29.03{ }^{\circ} \mathrm{C}$ (Group 1) While samples water stored and exposed to mild and intense sunlight ranged $29.8{ }^{0} \mathrm{C}-30.6{ }^{\circ} \mathrm{C}$ (Group 2 and 3) as shown in fig. 1 below. This is similar to the previous report elsewhere (Anake et al. 2013). Increase in warmness of an environment favours the growth of microorganisms and this can affect the taste and odour of the water samples (Sunday et al. 2011).

Turbidity values in all the brand of water samples analyzed (Bottle and Sachet) were found to be less than 5 NTU for all the water samples exposed to different conditions of storage (initial, mild and intense). This is similar to the results obtained in the previous work (Anake et al. 2013). The turbidity values recorded were all within acceptable limits of 5 NTU (WHO 2011; SON 2007) as shown in table 1 below. 
Conductivity values in different brands of water samples (sachet and bottle) ranged from $45.33 \mu \mathrm{S} / \mathrm{cm}$ - $160.1 \mu \mathrm{S} / \mathrm{cm}$. Water samples analyzed immediately (Group 1) ranged from 89.9 $146.90 \mu \mathrm{S} / \mathrm{cm}$. While water samples exposed to mild (group 2) and intense sunlight exposure ranged (group 3) ranged from $49.551 \mu \mathrm{S} / \mathrm{cm}-131.301 \mu \mathrm{S} / \mathrm{cm}$ and $53.941 \mu \mathrm{S} / \mathrm{cm}-147.201 \mu \mathrm{S} / \mathrm{cm}$ respectively. This is similar to previous work reported in the literature (Sheshe and Magashi 2014; Shalom et al. 2011). Sample A and C (Group 1) recorded the lowest in both sachet and bottle water respectively. While sample B and C (intense) recorded the highest conductivity value. It was observed from these results that there is an increase in conductivity values of water brands exposed to intense sunlight for six weeks.

The TDS concentrations of the water samples in all the brands ranged from $22.03 \mathrm{mg} / \mathrm{L}-81.00$ $\mathrm{mg} / \mathrm{L}-81.00 \mathrm{mg} / \mathrm{L}$ for both sachet and bottle water brands. A similar result was reported elsewhere (Shalom et al. 2011). While water samples (sachet and bottle) stored under mild (group2) and intense (group 3) sunlight exposure ranged from 22.03mg/L - $65.7 \mathrm{mg} / \mathrm{L}$ and $23.51 \mathrm{mg} / \mathrm{L}-73.60$ $\mathrm{mg} / \mathrm{L}$ respectively as shown in fig. 1 below. TDS was found to be within the permissible limit of $500 \mathrm{mg} / \mathrm{L}$ as shown in table 1 below. The highest TDS concentration was recorded in A (sachet water) and B (bottle water) brands. While the least TDS concentration was recorded in A (sachet) and $\mathrm{C}$ (bottle) water brands.
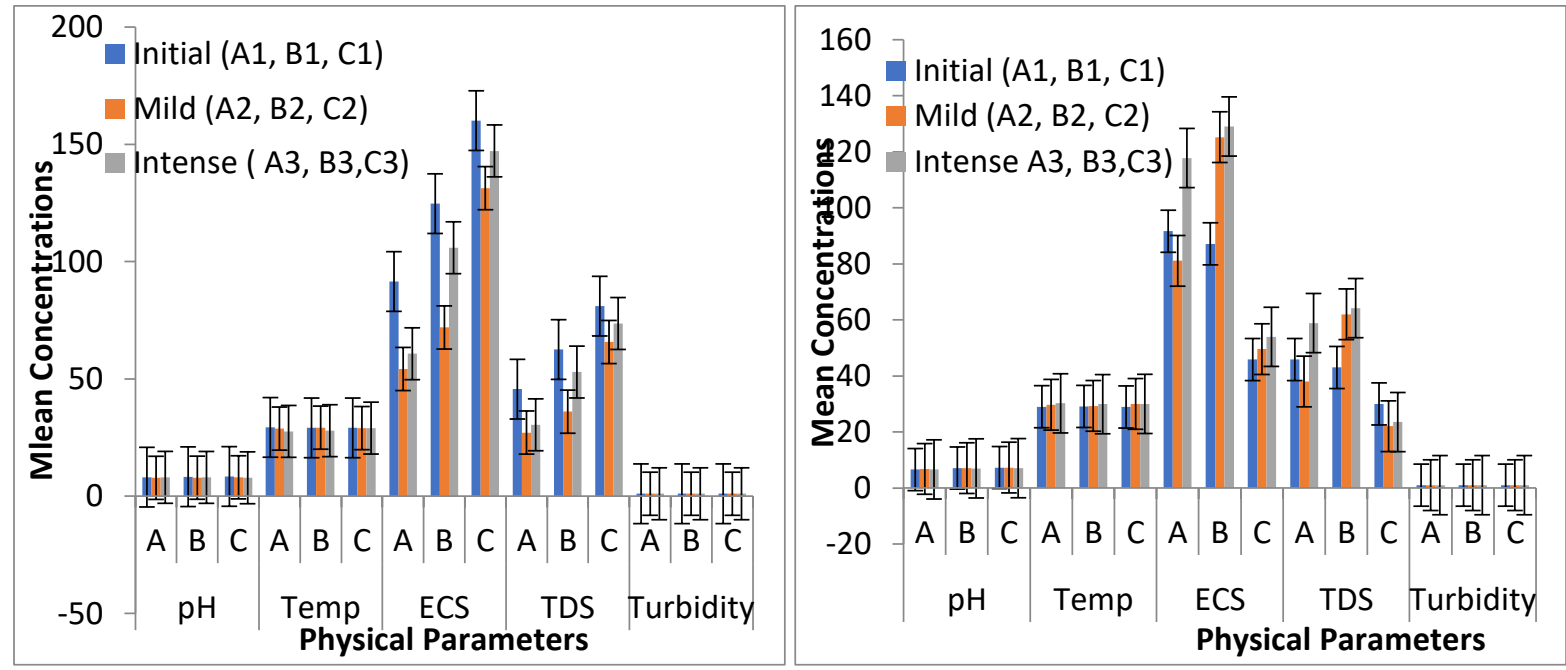

Fig. 1.Showing Variation of Physical Parameters in sachet water (a) and bottle water groups (b) 
Table 1. Permissible limits set by WHO and SON

\begin{tabular}{lll}
\hline & \multicolumn{2}{l}{ Maximum Permissible limits } \\
Parameter & WHO $^{\mathbf{a}}$ & SON $^{\mathbf{b}}$ \\
\hline $\mathrm{pH}$ & $6.5-8.5$ & $6.5-8.5$ \\
Temperature & $35-40$ & Ambient \\
Electrical Conductivity & $1000 \mu \mathrm{s} / \mathrm{cm}$ & $1000 \mu \mathrm{s} / \mathrm{cm}$ \\
Total Dissolved Solids & $500 \mathrm{mg} / \mathrm{L}$ & $500 \mathrm{mg} / \mathrm{L}$ \\
Turbidity & $5 \mathrm{NTU}$ & $5 \mathrm{NTU}$ \\
Total Hardness & $100 \mathrm{mg} / \mathrm{L}$ & $150 \mathrm{mg} / \mathrm{L}$ \\
Calcium & $200 \mathrm{mg} / \mathrm{L}$ & \\
Magnesium & - & - \\
Chloride & $100 \mathrm{mg} / \mathrm{L}$ & $250 \mathrm{mg} / \mathrm{L}$ \\
Sulphate & $100 \mathrm{mg} / \mathrm{L}$ & $100 \mathrm{mg} / \mathrm{L}$ \\
Nitrate & $10 \mathrm{mg} / \mathrm{L}$ & $50 \mathrm{mg} / \mathrm{L}$ \\
Alkalinity & $200 \mathrm{mg} / \mathrm{L}$ & $\mathrm{NA}$ \\
Chromium & $0.10 \mathrm{mg} / \mathrm{L}$ & $0.05 \mathrm{mg} / \mathrm{L}$ \\
Lead & $0.015 \mathrm{mg} / \mathrm{L}$ & $0.01 \mathrm{mg} / \mathrm{L}$ \\
Total bacteria count & 0 & 0 \\
Total Coliform Count & 10 & 10 \\
Faecal Coliform Count & 0 & 0 \\
Total Fungal Count & 0 & 0 \\
\hline * WHO ( 2006, 2011) & $* \mathrm{SON}^{\mathrm{b}}(2007) * \mathrm{NA}=\mathrm{Not}$ available $* \mathrm{NA}=\mathrm{Not}$ Available
\end{tabular}

Total hardness concentration $(\mathrm{TH})$ ranged from $20.0 \mathrm{mg} / \mathrm{L}-80.0 \mathrm{mg} / \mathrm{L}$ for all the three brands of water (sachet and bottle) stored under different conditions. The hardness values recorded were all within WHO acceptable limits (100 mg/L). TH of the water samples (sachet and bottle) stored under mild sunlight exposure (Group 2) ranged 20.0mg/L-76.0 mg/L while those stored at intense sunlight condition (Group 3) ranged from $24.00 \mathrm{mg} / \mathrm{L}-80.0 \mathrm{mg} / \mathrm{L}$. A similar result was obtained elsewhere (Sheshe and Magashi 2014). The highest value was also recorded in sample A (sachet) and $\mathrm{C}$ (bottle water) and the least value was recorded in sample A (sachet water) and C (bottle water) as shown in fig. 2 below. There was an increase in the value of hardness when subjected to both mild and intense sunlight conditions.

Chloride concentration ranged from $0.43 \mathrm{mg} / \mathrm{L}-41.83 \mathrm{mg} / \mathrm{L}$ for all the three brands of water stored under different sunlight exposure. The highest concentration value of $41.83 \mathrm{mg} / \mathrm{L}$ Chloride was recorded in sample $\mathrm{C}$ and A of sachet water (fig.2a) While $1.03 \mathrm{mg} / \mathrm{L}$ of Chloride was recorded in bottle water (fig. 2b). While the least value recorded $26.2 \mathrm{mg} / \mathrm{L}$ (sachet) and $0.43 \mathrm{mg} / \mathrm{L}$ (bottle) in sample B and A respectively. The chloride values of water samples stored under mild (Group 1)

$222 \mathrm{mg} / \mathrm{L}$ respectively. 
Calcium $(\mathrm{Ca})$ concentration ranged from $11.33 \mathrm{mg} / \mathrm{L}-54.00 \mathrm{mg} / \mathrm{L}$ for all the three brands of water

225

226

227

228

229 samples in all the groups (initial, mild and intense) for both sachet and bottle water. This result followed a similar trend previously reported (Anuonye et al. 2012) The highest value of calcium was recorded in sample $\mathrm{C}$ with concentration of $54.00 \mathrm{mg} / \mathrm{L}$ and the lowest was recorded in sample B $(11.33 \mathrm{mg} / \mathrm{L})$. The concentration of Calcium was found to be lower than permissible limit set by WHO as indicated on the table 1 above. The concentration of magnesium in all the water samples analyzed ranged from $6.00-30.00 \mathrm{mg} / \mathrm{L}$ in all the three brands of water used for this study. The results obtained were found to be higher than the previous reports elsewhere (Afolabi et al. 2012; Orosun et al. 2016). Higher concentration of magnesium is known to cause water hardness, cathartic and diuretic effect in human body (APHA 1985)

The concentration of Sulphate was found to be lower in bottle water $(0.01 \mathrm{mg} / \mathrm{L}-0.038 \mathrm{mg} / \mathrm{L})$ than the concentration of sulphate in sachet water $(0.013-0.148 \mathrm{mg} / \mathrm{L})$. The concentration of sulphate reported in a similar work is higher when compared to what is obtained in previous work (Sulaiman et al. 2011; Ojekunle et al. 2015). The concentration of sulphate was found to be lower than permissible limit $(100 \mathrm{mg})$.

Alkalinity values ranged from $2.00 \mathrm{mg} / \mathrm{L}-8.00 \mathrm{mg} / \mathrm{L}$ for all the water brand samples investigated. It was observed that there is a variation in concentration of the water samples exposed to various condition (mild and intense sunlight exposure). High values of Alkalinity were observed in a similar work when compared to the alkalinity values reported in this work (Ojekunle et al. 2015; Toma et al. 2013). The values of nitrate obtained in water samples ranged from $2.1 \mathrm{mg} / \mathrm{L}-8.0$ $\mathrm{mg} / \mathrm{L}$. The nitrate value recorded ranged from $3.9-7 \mathrm{mg} / \mathrm{L}-7.0 \mathrm{mg} / \mathrm{L}$ and $2.0 \mathrm{mg} / \mathrm{L}-8.0 \mathrm{mg} / \mathrm{L}$ respectively in sachet (fig. 3a) and bottle (fig. 3b) water. This is similar to the previous work in the literature work (Ojekunle et al. 2015; Toma et al. 2013). The nitrate contents in all the brands of water investigated were below the permissible limits (WHO 2006; SON 2007; WHO 2011) as shown in table 1 above. 

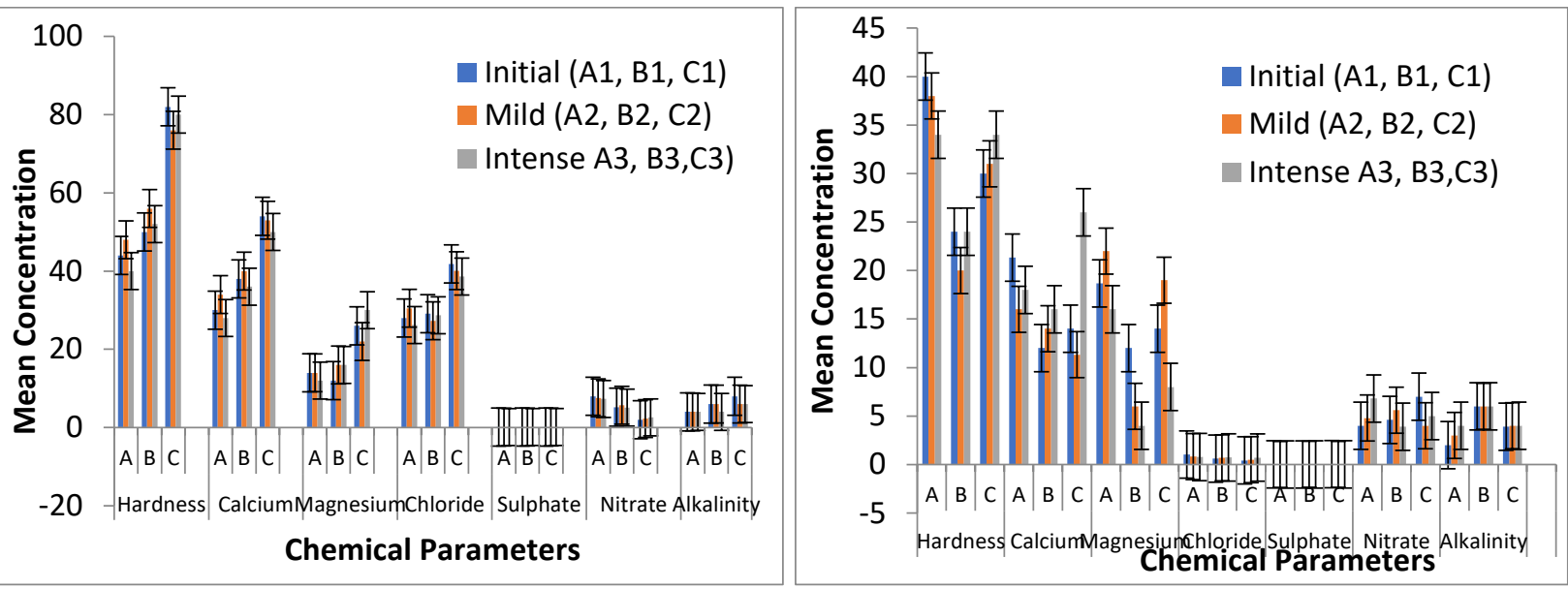

252

253

254

255

256

257

258

259

260

261

262

263

264

265

266

267

268

269

270

271

272

273

274

275

Fig. 2. Showing Variation of Chemical Parameters in sachet water (a) and bottle water groups (b)

Chromium value ranged from $0.15 \mathrm{mg} / \mathrm{L}-0.51 \mathrm{mg} / \mathrm{L}$ for all the water samples analyzed under different conditions of storage which was found to be higher than the permissible limit set by both SON and WHO (Table 1). Cr contents ranged from $0.14 \mathrm{mg} / \mathrm{L}-0.22 \mathrm{mg} / \mathrm{L}$ and $0.16 \mathrm{mg} / \mathrm{L}-0.51$ $\mathrm{mg} / \mathrm{L}$ ) in both sachet (fig. 3a) and bottle water samples respectively (fig. 3b). This result followed a similar trend by previous researcher (Muhammad and Fanan 2012). Chromium (Cr) at a very high concentration is known to be toxic to human and can cause cancer. Lead value ranged from $0.13 \mathrm{mg} / \mathrm{L}-0.38 \mathrm{mg} / \mathrm{L}$ for all the brand of water samples. The highest concentration of $\mathrm{Pb}$ was found in sample A (sachet) and sample C (bottle) with the least. The concentration of Lead increases gradually when exposed to various conditions as compared to that of the initial analysis. The presence of Lead in high concentration can damage nervous connection (especially in young children), cause blood and brain disorder, it is also a cumulative poison and a possible human carcinogen (Wani et al. 2015). The concentration of lead in all samples from different brand was found to be higher than the acceptable limits of $0.015 \mathrm{mg} / \mathrm{L}$ and $0.01 \mathrm{mg} / \mathrm{L}$ respectively (WHO 2006; SON 2007; WHO 2011) as shown in table 1 above.

The mean concentrations of Iron obtained in all the water samples ranged from $0.55 \mathrm{mg} / \mathrm{L}-1.11$ $\mathrm{mg} / \mathrm{L}$ (F. This result is similar to the results earlier reported in the literature (Anake et al. 2013; Akuffo et al. 2013). Highest concentration recorded in sample B (sachet) and the least concentration in sample A (bottle). Iron concentrations ranged from $0.55 \mathrm{mg} / \mathrm{L}-1.06 \mathrm{mg} / \mathrm{L}$ and $0.69 \mathrm{mg} / \mathrm{L}-1.11 \mathrm{mg} / \mathrm{L}$ respectively for samples stored under mild and intense sunlight condition (fig. 3). There is a variation in the values of all the parameters checked on all the brand of water samples stored under different condition of storage (initial, mild and intense exposure to sunlight). 
This could be as a result of the geochemistry of the soil of the water samples and water treatment methods employed.

278

279
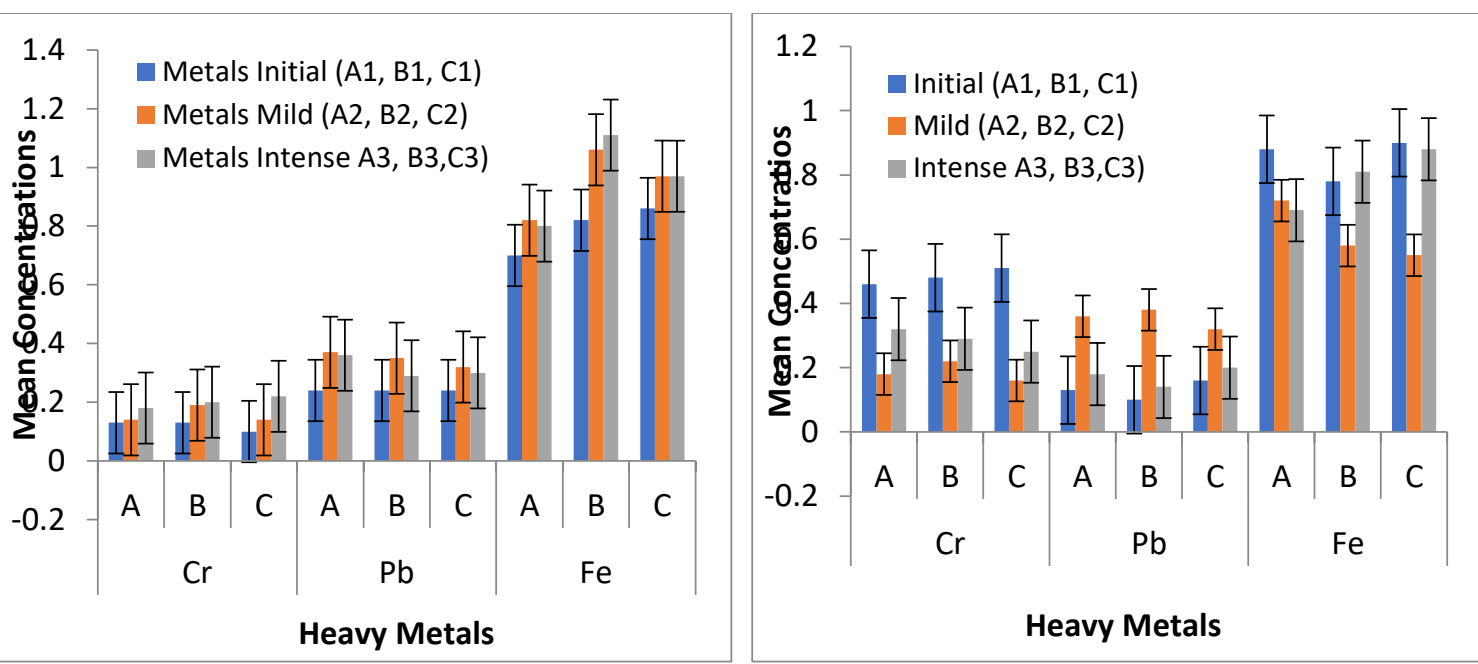

Fig. 3. Showing Variation in Heavy Metal Analysis of sachet Water (a) and bottle water groups (b)

The Hazard Quotient (HQ) estimated for all the heavy metals in all the three (3) water groups (i.e. initial, mild and intense condition) are within the recommended safe limit $(<1)$ ) set by USEPA (2001). The total HI for initial, mild and intense condition group are $0.8373,0.6620$ and 0.6664 respectively for bottle water and $0.1874,0.2446$, and 0.2512 respectively for sachet water (Fig. 4a). These values are within the recommended safe limit $(<1)$ set by USEPA (2001) and therefore means that the general populaces are not in great danger of non-carcinogenic health effects of these heavy metals. While the mean HI value for the initial conditioning appears to be greater than mild and intense conditioning category for the bottle water, reverse is the case with sachet water where the mean HI value for the intense conditioning is greatest.

The Incremental Lifetime Cancer Risk (ILCR) was estimated and the mean values for initial, mild and intense condition group are: 6.94E-03, 2.75E-03, and 4.14E-03 respectively for the bottle water and $8.86 \mathrm{E}-4,1.16 \mathrm{E}-3$ and 1.47E-3 respectively for the sachet water (Fig. 4b), with $\mathrm{Cr}$ contributing most to the cancer risk in both cases. Owing to the fact that cancer risks greater than 1.00E-4 are considered high since they pose higher cancer risk and values below 1.00E-6 are considered not to pose any cancer risk to humans, it follows that the cancer risks are high for the three (3) water groups (i.e. initial, mild and intense condition) for both sachet and bottle water. Since the result reveals values of ILCR that are $100 \%$ higher than the recommended limit, the general populace are in danger of carcinogenic health effect. However, it is noteworthy that the reported carcinogenic and non-carcinogenic risk values in this study may be undervalued because 
the appraisals did not capture intakes from other metals like arsenic, cadmium, nickel, etc. and the exposure parameters (i.e. EF, AT, BW and ED) used were adopted from USEPA, so might not ineludibly represent a typical Nigerian case.
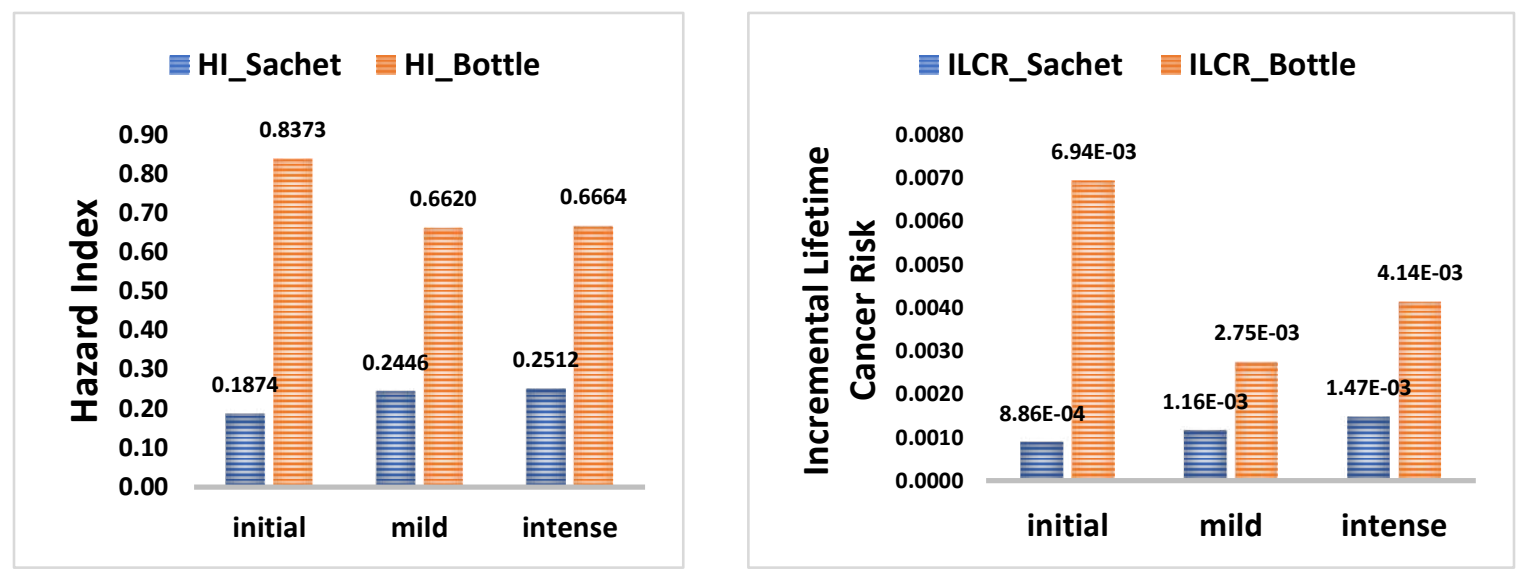

Fig. 4. Showing Hazard Index (a) and Incremental Lifetime Cancer Risk for all the water groups (b) The value of Total bacteria count (TBC) ranged from $6.5 \mathrm{Cfu} / 100 \mathrm{ml}-124.5 \mathrm{Cfu} / 100 \mathrm{ml}$ for all the water samples. The highest value was recorded in sample $\mathrm{C}$ (sachet) and the least value was recorded in sample A (bottle). TBC value for samples under mild and intense sunlight condition ranged from $14.5 \mathrm{Cfu} / 100 \mathrm{ml}-124.55 \mathrm{Cfu} / 100 \mathrm{ml}$ and $21.55 \mathrm{Cfu} / 100 \mathrm{ml}-84.0 \mathrm{Cfu} / 100 \mathrm{ml}$ respectively. This follows a similar trend to reported elsewhere (Anuonye et al. 2012). This is because a warm environment favours the growth of bacteria and very high temperature reduces the growth of this bacteria. The TBC found in all the water samples were found to be higher than permissible limits (WHO 2006; SON 2007; WHO 2011) as shown in table 1 above.

The value of Total coliform count (TCC) ranged from $0.5 \mathrm{Cfu} / 100 \mathrm{ml}-37.5 \mathrm{Cfu} / 100 \mathrm{ml}$ for all the water samples. TCC values ranged from $0.5 \mathrm{Cfu} / 100 \mathrm{ml}-5.0 \mathrm{Cfu} / 100 \mathrm{ml}$ and $1.0 \mathrm{Cfu} / 100 \mathrm{ml}-37.5$ $\mathrm{Cfu} / 100 \mathrm{ml}$ in both bottle and sachet water respectively. The result obtained in this study is higher than previous report in assessment of the quality of water before and after storage in the Nyankpala Community of the Tolon-Kumbungu District, Ghana (Akuffo et al. 2013). Brand A water samples has no TCC value in bottle water when compared to other brand water samples and the highest value was recorded in bottle water. This is indicating that most of the bottle water analyzed were below the limit while sachet water analyzed were found to be above limits.

Faecal coliform values ranged from $0.5 \mathrm{Cfu} / 100 \mathrm{ml}-2.5 \mathrm{Cfu} / 100 \mathrm{ml}$ and $0.5 \mathrm{Cfu} / 100 \mathrm{ml}-1.0$ $\mathrm{Cfu} / 100 \mathrm{ml}$ in both bottle and sachet water respectively. It was observed that samples of water 
analyzed immediately (Brand A, B C) has no FCC and as the temperature increases there is an increase in FCC of the water samples exposed to mild and intense temperature. Most of the water samples investigated were above the threshold limit sets as indicated in the table 1 above.

Total fungi count (TFC) was not detected in all the brand of bottle water samples stored under different conditions (initial, the mild sunlight and intense condition). TFC found in all the sachet water samples ranged from $0 \mathrm{Cfu} / 100 \mathrm{ml}-2.0 \mathrm{Cfu} / 100 \mathrm{ml}$ which are higher than the permissible limit by WHO and SON. TFC done on all the brands of water analyzed at zero day (initial) has 0 $\mathrm{Cfu} / 100 \mathrm{ml}$ for all the brand water samples but those water samples stored at mild sunlight exposure has higher TFC $(0.6 \mathrm{Cfu} / 100 \mathrm{ml}-2.0 \mathrm{Cfu} / 100 \mathrm{ml})$ than those stored under intense sunlight exposure $(0.5 \mathrm{Cfu} / 100 \mathrm{ml}-1.1 \mathrm{Cfu} / 100 \mathrm{ml}$ This is because microbes will not survive at higher temperature.

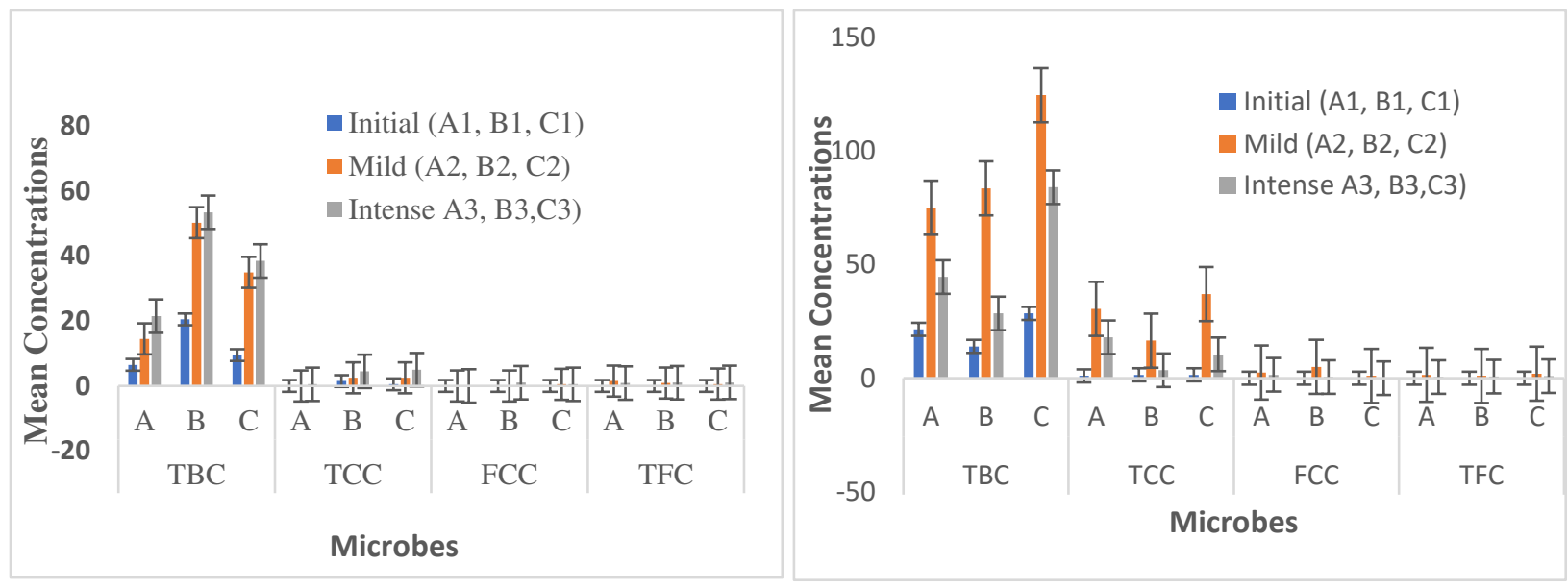

Fig. 5. Showing the Variation of Microbial Analysis in sachet water (a) and bottle water groups (b)

\section{CONCLUSION}

Water is a liquid needed at all time for several human activities. This study revealed that the samples taken to the laboratory were operating within the WHO limits for physicochemical guidelines for drinking water regardless of the mode of storage. Heavy metal concentrations were found to be above the limits set by WHO/SON in all the water samples analyzed. While the corresponding carcinogenic risks revealed values that are higher than the recommended safety range, the non-carcinogenic risk assessment reveals values within the acceptable limits. This reveals that the general populace is in danger of carcinogenic health effect. TFC was found to be present in both mild and intense storage condition of both sachet and bottle water but absent in initial storage condition which proved that water stored under high temperature increases microbial growth in water. TBC and FCC counts were found to be higher in the permissible limits set by 
WHO and SON for all the water samples analyzed (sachet and bottle) irrespective of the storage condition which makes the samples of water analyzed not safe for human consumption. However, proper monitoring and compliance to drinking water standards is adequately required by various agencies.

\section{REFERENCE}

APHA (1985). Standard methods for examination of water and waste water. American Public Health Association.16 edition. Washington, D C. $23-29$

APHA (1998) Standard methods for the examination of water and wastewater. $20^{\text {th }}$ (Eds). Clesceri LS, Greenberg AE, \& Eaton, AD, (Eds); American Public Health Association: Washington, DC

APHA (2017) Standard methods for the examination of water and wastewater. $20^{\text {th }}$ ed. Washington, USA: American Public Health Association, American Water Works Association

ATSDR (2007). U.S. Agency for Toxic Substances and Disease Registry. http://www.atsdr.cdc.gov/mrls/ (accessed 25 November, 2020)

Adegoke OA, Bamigbowu EO, Oni ES, Ugbaja KN (2012) Microbiological Examination of Sachet Water Sold in Aba, AbiaState, Nigeria. Global Res. J. Microbiol. 2 (1):62 - 66

Afolabi TA, Ogbuneke CC, Ogunkunle OA, Bamiro FO (2012) Comparative assessment of the potable quality of water from Industrial, urban and rural Parts of Lagos, Nigeria. Ife J. Sci. 14(2):221 - 232

Akinde, SB, Nwachukwu, MI, Ogamba AS (2011) Storage effects on the quality of sachet water produced within Port Harcourt metropolis, Nigeria. J. Biolog. Sci. 4:157-164

Akuffo, I, Cobbina SJ, Alhassan EH, Nkoom M (2013) Assessment of the Quality of Water Before and After Storage in the Nyankpala Community of the Tolon-Kumbungu District, Ghana. Int J Sci Technol Res 2(2):221 - 227

Anake WU, Ehi-Eromosele CO, Siyanbola TO, Edobor-Osoh A (2013) Adeniyi, I.O.; Taiwo, O. S. Physico-Chemical and Microbial Assessment of Different Water Sources in Ota, Ogun State, Nigeria Int. J. Current Res. 5(7):1797 - 1801

Anuonye JC, Maxwell OM, Caleb MY (2012) Quality of sachet water produced and marketed in Minna metropolis, North Central Nigeria. Afr. J. Food Sci. 6(24):583 - 588

Chapagain, A.; Hoekstra, A. (2007) Water Footprints of Nations: Water Use by People as a Function of Their Consumption Pattern. Water Res Manag 21(1):35 - 48

Duru CE, Amadi US, Enyoh CE (2017) Storage and its Effect on Chemical Quality Indicators in Sachet Water Brands Sold in Owerri Municipal, Imo State, Nigeria. World News of Nat Sci 12:73 - 81

Edema, MO, Atayese AO, Bankole MO (2011) Pure water syndrome: bacteriological quality of sachetpacked drinking water sold in Nigeria. Afr J Food Nutri Dev 11 (1): 4609 - 4595 
Haque A, Jewel A, Ferdoushi Z, Begum M, Husain I, Mondal S (2018). Carcinogenic and Noncarcinogenic Human Health Risk from Exposure to Heavy Metals in Surface Water of Padma River. Res J Environmental Toxicol 12(1):18-23

Isinkaye OM (2018) Distribution and multivariate pollution risks assessment of heavy metals and natural radionuclides around abandoned iron-ore mines in North Central Nigeria. Earth Sys Environ $2(2): 331-343$

Kendall P (2007) Drinking Water Quality and Health. No. 9.307. Colorado State: Colorado State University Extension Food Science and Human Nutrition. p. 24

Li F, Qiu Z, Zhang J, Liu C, Cal Y, Xiao M. (2017). Spatial distribution and fuzzy health risk assessment of trace elements in surface water from Honghu Lake. Int. J. Environ. Res Public Health 14(9):1101 - 1119

Muhammad MA, Fanan U (2012) Assessment of the Chemical Quality of Potable Water Sources in Abuja, Nigeria. British J Appl Sci Technol 2(2):146 - 172

Ojekunle, ZO, Ojekunle VO, Eruola AO, Oyebanji FF, Olatunde KA, Amujo BT, Sangowusi, OR, Adekitan AA, Taiwo AG (2015) The Effects of Storage on Sachet Water Quality in Ogun State, Nigeria. J Appl Sci Environ Manage 19(2):183 - 189

Oparaocha ET, Iroegbu OC, Obi RK (2010) Assessment of Quality of Drinking Water Sources in the Federal University of Technology, Owerri, Imo State, Nigeria. J Appl Biosci 32:1964 - 1976

Orosun MM, Tchokossa P, Nwankwo LI, Lawal TO, Bello SA, Ige SO (2016) Assessment of Heavy Metal Pollution in Drinking Water Due to Mining and Smelting Activities in Ajaokuta, Nigeria. Nigerian J.Technolog. Develop 13(1):31 - 39

Orosun MM, Adewuyi AD, Salawu NB, Isinkaye MO, Orosun AR, Oniku AS (2020). Monte Carlo approach to risks assessment of heavy metals at automobile spare part and recycling market in Ilorin, Nigeria. Sci Rep 10 (2020):22084

Orosun MM (2021). Assessment of Arsenic and Its Associated Health Risks Due to Mining Activities in Parts of North-Central Nigeria: Probabilistic Approach Using Monte Carlo. J Hazard Mater 412:25262

Oyelude EO, Ahenkorah S (2012) Quality of sachet water and bottled water in Bolgatanga Municipality of Ghana. Res J Applied Sci Engineer Technol 4:1094 - 1098

Rinklebe J, Antoniadis V, Shaheen SM, Rosche O, Altermann M (2019). Health risk assessment of potentially toxic elements in soils along the Central Elbe River, Germany. Environ Int 126:76 - 88

Shalom NC, Obinna CN, Adetayo YO, Vivienne NE (2011) Assessment of water quality in Canaanland, Ota, Southwest Nigeria. Agri Biolog J North America. 2(4):577 - 583 
Sheshe MU, Magashi AM (2014) Assessment of Physicochemical Quality of Sachet Water produced in selected Local Government Areas of Kano Metropolis, Kano State - Nigeria. Bayero J Pure Appl Sci 7(2):31 - 35

Singh S, Mosley LM (2003) Trace metal levels in drinking water on Viti Levu, Fiji. Islands. J Natural Sci. 21:31 $-34$

SON (2007) Nigerian Standard for drinking water quality, p 15

Sulaiman GM, Lawen SE, Shelear HH (2011) Effect of storage temperature and sunlight exposure on the physicochemical properties of bottled water in Kurdistan region-Iraq. J Appl Sci Environ Manage 15 (1):147 - 154

Sunday, B. A.; Michael, I. N.; Adindu, S. O. Storage Effects on the Quality of Sachet Water Produced within Port Harcourt Metropolis, Nigeria. Jordan J Biolog Sci 4(3):157 - 164

Tambekar DH, Hirulkar NB, Bhokre DD, Gulhane SR, Bhanginwar YS (2006) Studies of Hygiene behaviour on bacteriological quality deterioration of water in Hotels and Restaurants. Res $\quad$ J Microbiolog 1:183 - 189

Toma JJ, Hanna NS, Mohammed BA (2013) Effect of storage condition on some bottled water quality in Erbil City, Kurdistan Region-Iraq. IntJ Software Web Sci 3 (1):33 - 43

Tortora JG, Funke RB, Case LC (2002) Microbiology An introduction. Media update of 7 Edition.including bibliography and index publisher. Daryl Fox 258 -260

US EPA (2004) Risk Assessment Guidance for Superfund Volume I: Human Health Evaluation Manual (Part E, Supplemental Guidance for Dermal Risk Assessment) Final; Office of Emergency and Remedial Response, EPA/540/R/99/005, OSWER 9285.7-02EP PB99-９63312. July

US EPA) (2007). ProUCL Version 4.00.02 User Guide: Prepared by A. Singh, R. Maichle, A. K. Singh, S. Lee, N. Armbya, EPA/600/R- 07/038. April

US EPA (2009) Risk Assessment Guidance for Superfund Volume I: Human Health Evaluation Manual (Part F, Supplemental Guidance for Inhalation Risk Assessment), Office of Superfund Remediation and Technology Innovation, EPA-540-R-070-002, OSWER 9285.7-82. January

UNC (2011) Updated Baseline Human Health Risk Assessment, Church Rock Tailings Site, Church Rock, New Mexico

US EPA (2011) National Primary Drinking Water Regulations. Retrieved from http://water.epa.gov/drink/contaminants/index.cfm\#List

US EPA (2001) Guidance for Characterizing Background Chemicals in Soil at Superfund Sites. Office of Emergency and Remedial Response, Washington, DC. OSWER Directive 9285.7 - 41

Uwah EI, Busari WR, Sayi A (2014) Physicochemical and Bacteriological Analyses of Sachets water samples in Kano Metropolis, Nigeria. IOSR J Appl Chem 6(6):52 - 56

Wani L, Ara A, Uswani JA (2015) Lead toxicity: a review. Interdisciplinary Toxicol 8(2): 55 - 64 
454 WHO (2011) Guidelines for drinking-water quality, fourth edition. Retrieved from 455 http://whqlibdoc.who.int/publications/2011/9789241548151_ eng.pdf (verified November $456 \quad 15,2011)$

457 WHO (2006) Guidelines for Drinking-Water Quality. First Addendum to Third Edition. Volume 1:

458 Recommendations. Geneva, Available at:

459 http://www.who.int/water_sanitation_health/dwq/gdwq0506.pdf 